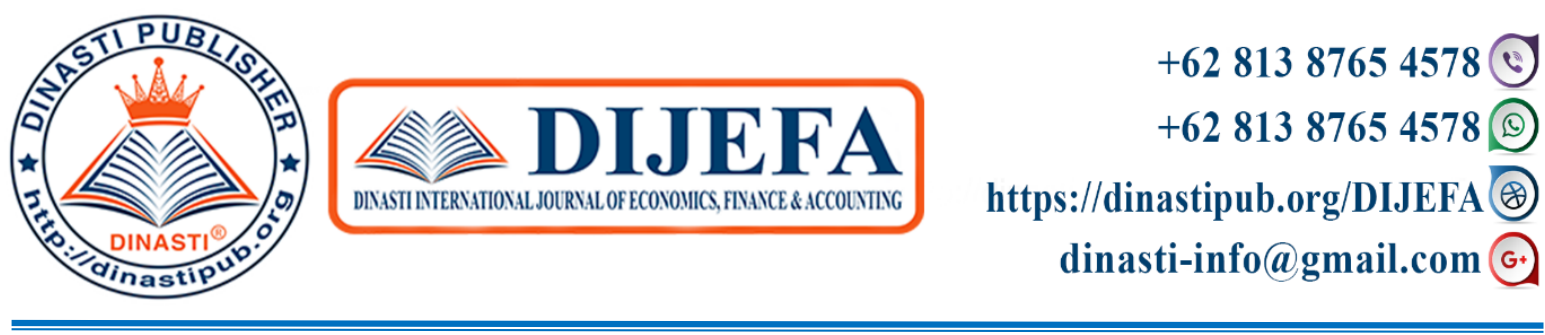

\title{
INFLUENCE COMPENSATION, CAREER DEVELOPMENT AND JOB SATISFACTION TO TURNOVER INTENTION
}

\author{
Margo Yonathan Purba ${ }^{1}$, Sangkala Ruslan ${ }^{2}$ \\ 1) Mercu Buana University, Jakarta, Indonesia \\ 2) Mercu Buana University, Jakarta, Indonesia
}

\begin{tabular}{|c|c|}
\hline $\begin{array}{l}\text { ARTICLE INFORMATION } \\
\text { Received: } 7 \text { August } 2020 \\
\text { Revised: } 25 \text { August } 2020 \\
\text { Issued: 24 September } 2020 \\
\text { Corresponding author: first author } \\
\text { E-mail: } \\
\text { margoyonathan@gmail.com }\end{array}$ & $\begin{array}{l}\text { Abstract: The purpose of this study aims to test and } \\
\text { analyze the effect of compensation, career } \\
\text { development and job satisfaction on employee } \\
\text { turnover intentions at PT. XYZ Research data is data } \\
\text { collected from interviews, questionnaires and } \\
\text { supporting data from PT. XYZ for } 3 \text { consecutive } \\
\text { years from } 2016 \text { to } 2018 \text {. The sampling method used } \\
\text { is the saturation sampling method. From a population } \\
\text { of } 156 \text { people, the sample used was } 113 \text { people as } \\
\text { well. The analytical method used in this study is } \\
\text { multiple linear regression analysis. The results } \\
\text { showed compensation, career development and job } \\
\text { satisfaction together (simultaneously) significantly } \\
\text { influence turnover intention. Partially shows that } \\
\text { compensation has a negative and significant effect on } \\
\text { turnover intention. Career development has a negative } \\
\text { and significant effect on turnover intentions. Job } \\
\text { satisfaction has a negative and significant effect on } \\
\text { turnover intentions. } \\
\text { Keywords: Compensation, Career development, Job } \\
\text { satisfaction, Turnover Intention }\end{array}$ \\
\hline
\end{tabular}

\section{INTRODUCTION}

The development of telecommunications technology has transformed the telecommunications industry in the world. The shift of voice and SMS telecommunications to data-based telecommunications is supported by the development of a massive internet. The availability of infrastructure networks and telecommunications access, in Indonesia has driven the growth of internet usage through wireless data access increasing rapidly. 
With the development of telecommunications technology which is increasingly increasing, companies engaged in the telecommunications technology industry must have competent human resources, because human resources are one of the important aspects in determining the quality and progress of a company. Human resources in question, namely employees, employees and laborers. The process of getting the best human resources in carrying out the company's organizational operations must be done in a professional and directed manner from sorting out prospective employees to be called in interviews, recruiting, training, developing, providing retribution to employee maintenance.

Companies that are not able to maintain the human resources they have, will cause many employees to leave, resulting in higher turnover values. Increased turnover will affect the high cost of re-recruiting new employees, so the presence of employees in the company needs to be considered and treated as the key to success for the company.

PT XYZ is a company engaged in services as a provider of telecommunications infrastructure \& construction services. PT XYZ has high attention to human resources. PT XYZ has high turnover data, along with the data:

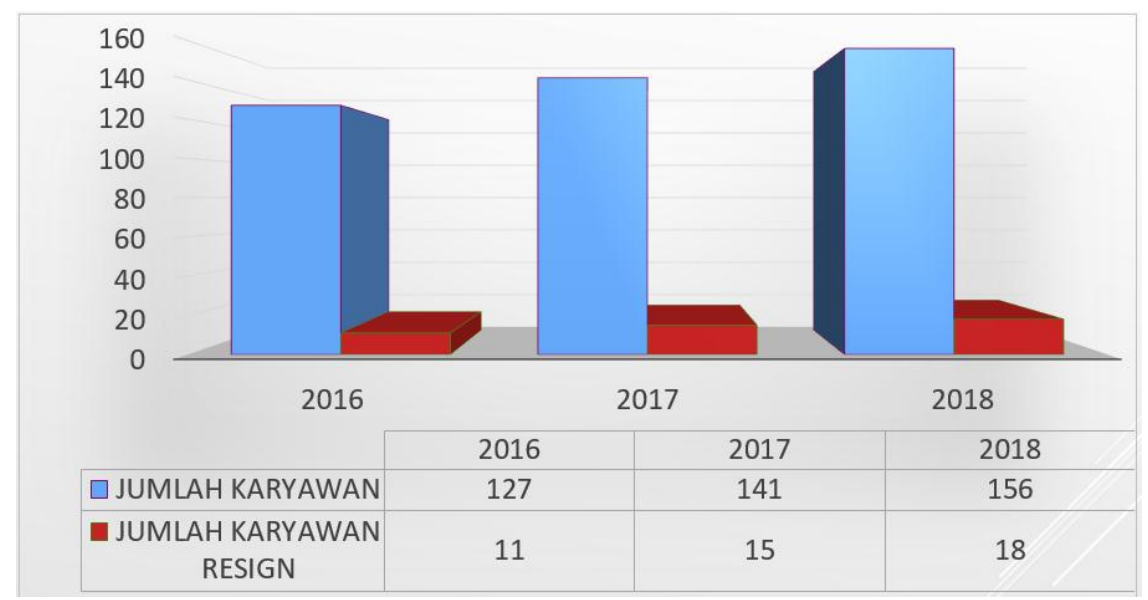

Figure 1. Turnover Data Graph Based on the number of employees resigned (source: XYZ company's internal, 2019)

Based on secondary data, the volume of PT XYZ employee resignations has continued to increase in the last 3 (three) years. Based on Figure 1.1, it can be calculated the percentage of employee resignations in 2016 of $8.6 \%$, in 2017 it increased to $10.6 \%$, and in 2018 it increased to $11.5 \%$. This is thought to be the problem of turnover intention in PT XYZ's work environment.

\section{LITERATURE REVIEW}

\section{Compensation}

According Mondy and Martocchio (2016: 247) means that compensation is the total of all awards given by the company to employees in return for employee contributions that have been given to the company. The overall purpose of compensation is to attract, retain, and motivate employees. According to Noe et.al (2014: 341) because salaries have an important effect on employees and cost considerations, organizations must plan to pay employees in every job. 
Where the salary of an employee is negotiated in an independent manner, there is a chance of feeling unfair, dissatisfied, so that certain positions will be difficult to fill.

Real rewards that employees receive for work come in the form of salaries, incentives, and benefits. Robert Mathis \& Jackson (2010) revealed that one key to retention is to have competitive compensation practices. Many managers believe that money is a major retention factor. Often, employees cite better salaries or higher compensation at other companies as a reason for leaving the company.

\section{Career Development}

According to Mondy and Martocchio (2016: 234) career development is a formal approach that organizations use for people with the right qualifications and e perience available when needed. According to Kasmir (2016: 151) stated that a career is a position and rank obtained by an employee as long as the employee works at a company. This means that during a work will increase career position and rank.

Robert Mathis \& Jackson (2010) in a book entitled "Human Resource Management" states the survey of workers in all types of work consistently shows that if an organization strives to help career development, it can significantly affect employee turnover. This survey has proven that career development is a reason why an employee decides to take a job in a company and an employee's reason why staying in a company or organization.

\section{Job Satisfaction}

Robbins \& Judge (2013: 79) defines job satisfaction as positive feelings about work that result from evaluating its characteristics. Then Usman et al (2019) e plained that job satisfaction is the level of individual satisfaction that they are rewarded according to various aspects of the work situation of the organization where they work. Thus, job satisfaction involves psychological individuals in the organization, which is caused by the circumstances he feels from his environment and those feelings will appear from the positive attitude of employees to work and everything that is encountered in his work environment, Hidayat et al (2018).

Robert Mathis \& Jackson (2010) in a book called "Human Resource Management" states that if someone does not fit into their work, they are more likely to look for another job. So employee retention is influenced by the suitability of an employee's position in doing a job. After an employee is placed in a job position, work factors greatly affect employee retention. Because an employee spends a lot of time in his work. So, an employee hopes to have modern equipment, high technology, and good working conditions. Field and environmental factors such as space, lighting, temperature, noise, work space layout, affect employee retention. In addition, workers want a safe and no-risk work environment.

\section{Turnover Intention}

According to Putrianti et al. (2014) turnover intention is the level or intensity of the desire to leave the company, many reasons cause this turnover intention and among other things are the desire to get a better job. This opinion is also relatively the same as the opinion e pressed previously, that the intention of turnover is basically a desire to leave or leave the company. At 
each company, employees can leave from time to time. Some researchers have suggested that having the intention to quit is the best predictor of turnover. Conceptual models and empirical models of turnover intentions provide strong support for propositions which state that behavioral intention forms the most important determinant of actual behavior (Putrianti et al., 2014).

\section{RESEARCH METHODS}

Based on the title and background of the problem previously discussed, this type of research falls into the category of causality research. According to Ferdinand (2014: 7) causality research is a form of research with the aim of seeking understanding of the causal relationship between more than one variable that has been developed in management.

According to Ferdinand (2014: 171) population is a combination of all the elements that can form events, things or individuals who have similar characteristics or characteristics and become the focus of a researcher.

Sampling in this study uses the category of nonprobability sampling in the form of saturated sampling. According to Indra and Cahyaningrum (2019: 54) nonprobability sampling is a way of determining samples where members of the population do not get the same opportunity during the sample selection process. According to Sugiyono (2014: 126) saturated sample is a sampling technique if all members in the population are sampled and this technique is often used in populations with small numbers or in studies that aim to generalize with relatively small error rates.

According to Ferdinand (2014: 229) descriptive statistics are used to get an empirical picture through data obtained through research where the types can be frequency distribution, average statistics or index numbers.

Validity test is carried out using the Statistical Package Service Solution (SPSS) number 25 program using correlations from Pearson Product Moment. The principle of validity testing on Pearson Correlation Product Moment is by connecting the score of each item with the total score obtained. The process of knowing whether an item is valid or not can be seen in the magnitude of significance where if the significance is less than 0.05 then the item is considered valid or valid but conversely if the significance is greater than 0.05 then an item is considered invalid or invalid. Another method is to compare the $r$ count (the result of data processing) with the $r$ table score (obtained from $r$ table), if the value is positive and $r$ the calculated result is greater than $r$ in the table then the item is considered valid, applies vice versa if $r$ count results are more smaller than $r$ in the table then the item is considered invalid (Purnomo, 2017: 70).

According to Ferdinand (2014: 218) a scale or measurement instrument is considered to be reliable if the instrument consistently or consistently produces relatively similar values each time a measurement is made. According to Herlina (2019: 70) the reliability test using the Cronbach alpha method is generally divided into categories:

- Cronbach's alpha with a value $<0.06=$ reliability is not good

- Cronbach's alpha with a value of $0.6-0.79=$ reliability is accepted

- Cronbach's alpha with a value $>0.08=$ good reliability

Normality test is used to see the value of residuals having a normal distribution or even having an abnormal distribution. The model in regression is said to be good if the value of the 
residuals is fairly or normally distributed. In the normality test that is tested is the residual value only and not each variable (Ansofino et al., 2016: 94). In this study the normality test used by the name Kolmogorof-Smirnov. According to Ismail (2018: 193) the Kolmogorof-Smirnov test was carried out by comparing the distribution of research data with the standard normal distribution in which the standard normal distribution was distributed in the form of z-scores.

Multicollinearity test is used to determine the presence and absence of a high relationship between each independent variable in the multiple linear regression model. If there is a high relationship between independent variables, it can interfere with the relationship that occurs between the independent variable and the dependent variable (Ansofino et al., 2016: 94). This multicollinearity test uses Pearson correlation on each independent variable.

Heteroscedasticity testing is used to determine the presence or absence of dissimilarities from one observation residual to another. A regression model can qualify if the residuals of observations from one to another have similar variance (Ansofino et al., 2016: 94). The method used in this heteroscedasticity test is Glejser. The Glejser method is done through the process of regressing independent variables on absolute residual values. If the significance value of the independent variable over the absolute residual value is greater than 0.05 , it is stated that there are no symptoms of heteroscedasticity.

According to Ghozali (2013: 96) multiple regression analysis is an analysis used to measure the effect of two or more independent variables on the dependent variable and also to determine the direction of the relationship that occurs between the independent variable and the dependent variable.

Multiple regression analysis is required to meet the requirements of the classic assumption test which has a normal distribution of data, non-multicollinearity and nonheteroscedasticity.

This study uses a hypothesis test in the form of a determination test (R2), F-test, t-test, and correlation test between dimensions.

F statistical test is used to determine whether the independent variables contained in the regression model have a joint or simultaneous effect on the dependent variable. The results of the $F$ test calculation are then compared with the $F$ table values. If the value of $F$ from the calculation results is greater than $\mathrm{F}$ in the table, together or simultaneously the independent variables affect the dependent variable. F-test decision making can be seen from the large significance. If the significance is below $5 \%$ or 0.05 , together or simultaneously the independent variable has an influence on the dependent variable, and vice versa if the significance is above $5 \%$ or 0.05 , then simultaneously or simultaneously the independent variable has no effect on dependent variable (Ma'arif in Wati and Primyastanto, 2018: 196).

Partial or t-test is used to find out individually or partial influence of the independent variable on the dependent variable. $T$ test is carried out by making comparisons of the calculated $t$ value with the $t$ value in the table or seeing the significance value. For example the value of $t$ arithmetic $>$ table $t$ and the value of the significance $<\alpha 0.05$ can be said to be the independent variable has a significant effect on the dependent variable. The reverse also applies if the value of $t$ arithmetic $<$ from $t$ table and the value of the significance $>\alpha 0.05$, it can be said 
that the independent variable does not have a significant effect on the dependent variable (Rusmana et al., 2019: 200)

The use of the coefficient of determination (R2) can get a picture of how closely the regression relationship between the independent variables with the dependent variable. The higher the value of $\mathrm{R} 2(0 \leq \mathrm{R} 2 \leq 1)$ the higher the estimate of a regression model (Nugraha, 2014: 191). The degree of determination coefficient can be calculated using the formula:

\author{
$\mathrm{BC}=\mathrm{r} 2 \times 100 \%$ \\ Information: \\ KD: Determination Coefficient Value \\ R2: Correlation Coefficient Value
}

Correlation analysis in statistical analysis is used to measure the level of relationship that occurs between the independent variables with the dependent variable. Correlation analysis between dimensions is used to determine the relationship of the dimensions of the independent variable to the dependent variable. Data processing in correlation analysis between dimensions uses SPSS (Statistical Product for Service Solution) version 25.

\title{
FINDINGS AND DISCUSSION
}

\section{Validity and Reliability Test}

The validity test results obtained valid items as many as 6 items of compensation variable, 6 items of career development variable, 6 items of job satisfaction variable, 9 items of turnover intention variable.

Reliability is related to the consistency and predictability test of a measuring instrument. The test is carried out by comparing the Cronbach Alpha number where the Cronbach Alpha value is at least 0.6 or $\geq 0.6$. If the value generated from the SPSS calculation results is greater than 0.6 then the questionnaire is reliable, if on the contrary it is not reliable. Here are the results of the reliability test to the variable Compensation (1), Career development (2), Job satisfaction ( 3), and Variable Turnover Intention (Y):

\begin{tabular}{lccc} 
& \multicolumn{3}{c}{ Table 1 Reability Test Result } \\
Variable & $\begin{array}{c}\text { Cronbach's } \\
\text { Alpha }\end{array}$ & Condition & Note \\
\hline Compensation & 0.905 & $>0.6$ & Reliable \\
\hline $\begin{array}{l}\text { Career } \\
\text { development }\end{array}$ & 0.903 & $>0.6$ & Reliable \\
\hline Job satisfaction & 0.907 & $>0.6$ & Reliable \\
\hline $\begin{array}{l}\text { Turnover } \\
\text { Intention }\end{array}$ & 0.964 & $>0.6$ & Reliable
\end{tabular}




\section{Normality Test}

The normality assumption test is carried out to test the data of the independent variable ( ) and the dependent variable (Y) in the resulting regression equation, whether it is normally distributed or not normally distributed. If the data distribution is normal, then data analysis and hypothesis testing are used parametric statistics. The normality test aims to test whether in the regression model the dependent variable and the independent variable both have normal distributions or not. A good regression model is having a normal or near normal distribution. The trick is to look at the Normal Probability Plot image. It can be said if the data points spread around the diagonal line and follow the direction of the diagonal line (Ghazali, 2016)

Table 2 Normality Test Results

One-Sample Kolmogorov-Smirnov Test

\begin{tabular}{|c|c|c|}
\hline \multicolumn{3}{|c|}{ Unstandardized Residual } \\
\hline $\mathrm{N}$ & & 113 \\
\hline \multirow[t]{2}{*}{ Normal Parameters ${ }^{a, b}$} & Mean & .0000000 \\
\hline & Std. Deviation & 4.67963628 \\
\hline \multirow[t]{3}{*}{ Most E treme Differences } & Absolute & .077 \\
\hline & Positive & .071 \\
\hline & Negative & -.077 \\
\hline \multicolumn{2}{|l|}{ Test Statistic } & .077 \\
\hline \multicolumn{2}{|l|}{ Asymp. Sig. (2-tailed) } & $.102^{\mathrm{c}, \mathrm{d}}$ \\
\hline \multicolumn{3}{|c|}{ a. Test distribution is Normal. } \\
\hline \multicolumn{3}{|l|}{ b. Calculated from data. } \\
\hline \multicolumn{3}{|c|}{ c. Lilliefors Significance Correction. } \\
\hline
\end{tabular}

Based on Table 2 the results of the Kolmogorov-Smirnov normality test, it can be seen that the Sig. $=0.102>\alpha=0.05$. Thus the Kolomogorov-Smirnov test results from the four variables above have met the normality requirements. This, it can be concluded that the data tested has a normal data distribution

\section{Multicollinearity Test}

The multicollinearity assumption test is used to measure the degree of association, closeness of relationships or linear relationships between independent variables. One of the multicollinearity tests commonly used is the Variance Inflation Factor (VIF) test, if the VIF value of the variable $<10$ then multicollinearity does not occur.

Table 3 Multicollinearity Test Results 


\begin{tabular}{lll} 
& \multicolumn{2}{c}{ Collinearity Statistics } \\
\cline { 2 - 3 } Model & Tolerance & VIF \\
\hline 1 (Constant) & & \\
\hline COMPENSATION & .227 & 4.409 \\
\hline CAREER DEVELOPMENT & .269 & 3.715 \\
\hline JOB SATISFACTION & .480 & 2.085 \\
\hline
\end{tabular}

(Source: data analysis result SPSS)

(Source: data processing, 2020)

Referring to table 3, the tolerance score for each variable is greater than 0.1 and the VIF value for each variable is smaller than 10 so that it can be concluded that the regression model in this study is free from multicollinearity between independent variables.

\section{Heteroscedasticity Test}

Multiple regression equations need to be tested whether or not the variant of one observation residual with another observation. If the residuals have the same variant, then it is called homoscedasticity, if if the variance is not the same, it is called heteroscedasticity. A good regression equation is if there is no heteroscedasticity. By using the Scatter Plot, the following results are obtained:

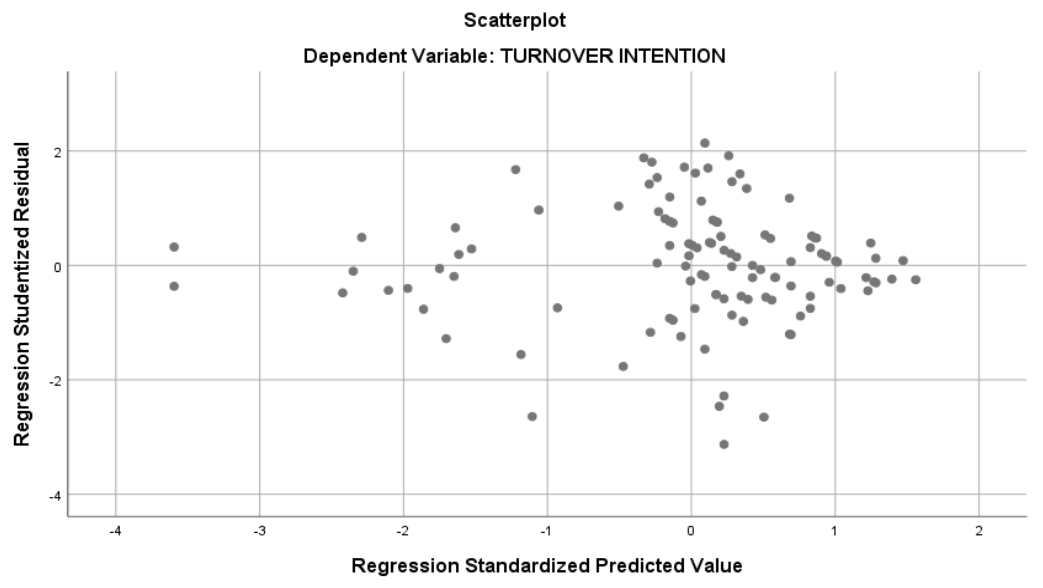

Figure 2. Heteroscedasticity Data Results

(Source: data processing, 2020)

Based on Figure 2, it appears that there are no clear patterns such as dots spreading above and below the number 0 on the $\mathrm{Y}$ a is, so the points spread randomly, and do not form certain patterns. It can be concluded that the data tested is free from heteroscedasticity

\section{Multiple Linear Regression Analysis}

Linear regression is needed to measure the magnitude of the relationship that occurs between two variables or it can be more. Linear regression is also needed in determining the direction of the strength of the relationship that occurs between the independent variable with the dependent variable, the direction can be positive or negative. Regression analysis in this 
study is used to analyze whether there is an influence of the independent variable Compensation (X1), Career Development (X2) and Job Satisfaction (X3) on the dependent variable, Turnover Intention (Y), and how much influence the independent variable has on the independent variable bound together. The following table will be presented based on the results of the multiple linear analysis test:

Tabel 4 Results of Multiple Linear Regression Analysis

Coefficients $^{\mathrm{a}}$

\begin{tabular}{|c|c|c|c|c|c|c|c|}
\hline \multirow{2}{*}{\multicolumn{2}{|c|}{ Model }} & \multicolumn{2}{|c|}{$\begin{array}{c}\text { Unstandardized } \\
\text { Coefficients }\end{array}$} & \multirow[b]{2}{*}{$\mathrm{t}$} & \multirow[b]{2}{*}{ Sig. (2-tailed) } & \multirow[b]{2}{*}{ Sig. (1-tailed) } & \multirow[t]{2}{*}{ Note } \\
\hline & & $\mathrm{B}$ & Std. Error & & & & \\
\hline \multirow[t]{4}{*}{1} & (Constant) & 55.527 & 1.688 & 32.891 & .000 & & \\
\hline & COMPENSATION & -.494 & .210 & -2.352 & .020 & .010 & $\begin{array}{c}\text { Significant Negative } \\
\text { Effect }\end{array}$ \\
\hline & $\begin{array}{l}\text { CAREER } \\
\text { DEVELOPMENT }\end{array}$ & -.699 & .189 & -3.694 & .000 & .000 & $\begin{array}{c}\text { Significant Negative } \\
\text { Effect }\end{array}$ \\
\hline & $\begin{array}{l}\text { JOB } \\
\text { SATISFACTION }\end{array}$ & -.352 & .156 & -2.249 & .027 & .013 & $\begin{array}{c}\text { Significant Negative } \\
\text { Effect }\end{array}$ \\
\hline
\end{tabular}

a. Dependent Variable: Turnover Intention

(Source: data processing, 2020)

Based on Table 4 in the Unstandardized Coefficients B column shows a constant value $(\alpha)$ of 55.527 and in the next row the coefficient of the independent variable (b) is Compensation of -0.494; Career Development is -0.699 and Job Satisfaction is -0.352 so the regression equation is arranged as follows:

$$
\begin{aligned}
& \mathrm{Y}=\alpha+\beta 1 \mathrm{X} 1+\beta 2 \mathrm{X} 2+\beta 3 \mathrm{X} 3+\mathrm{e} \\
& \mathrm{Y}=\text { 55.527 }-0.494 \mathrm{X} 1-0.699 \mathrm{X} 2-0.352 \mathrm{X} 3+\mathrm{e} \\
& \text { Information : } \\
& \mathrm{Y} \quad=\text { Turnover Intention } \\
& \alpha \quad=\text { Constant Value } \\
& \mathrm{X} 1 \quad=\text { Compensation } \\
& \beta 1 \quad=\text { Coefficient Estimation X1 } \\
& \mathrm{X} 2 \quad=\text { Career Development } \\
& \beta 2 \quad=\text { Coefficient EstimationX2 } \\
& \mathrm{X} 3 \quad=\text { Job Satisfaction } \\
& \beta 3 \quad=\text { Coefficient EstimationX3 } \\
& \mathrm{e}=\text { error }
\end{aligned}
$$

T-test 
T-test was conducted to find out the magnitude of the effect of the independent variables individually on the dependent variable. This t-test is also intended to estimate the extent of the contribution of changes that occur in each of the independent variables influencing the magnitude of changes in the dependent variable. The criteria for drawing conclusions from the t-test are explained in the sentence below:

- If the value of $t$ is calculated $>t$ in the table and the value of sig. $<0.05$ then $\mathrm{Ha}$ is accepted

- If the value of $t$ is calculated $<t$ in the table and the value of sig. $>0.05$ then $\mathrm{Ha}$ is declared rejected

$\mathrm{T}$ test results based on Table 4 can be concluded as follows:

1) There is a negative and significant influence from Compensation (X1) to Turnover Intention (Y) partially.

Table 4 shows that the relationship between Compensation (X1) and Turnover Intention $(\mathrm{Y})$ is significant with a $\mathrm{t}$-count of 2.352 ( $\mathrm{t}$-count $>\mathrm{t}$ table $=1.98)$ and a Sig. $=0.020$. The coefficient value is negative that is equal to -0.494 which indicates that the direction of the relationship between Compensation (X1) and Turnover Intention is negative at $49.4 \%$. Thus the $\mathrm{H} 1$ hypothesis in this study which states that "Compensation (X1) has a significant effect on Employee Turnover Intention (Y)" is accepted.

2) There is a negative and significant influence from Career development (X2) to Turnover Intention (Y) partially.

Table 4 shows that the relationship between Career development (X2) and Turnover Intention $(\mathrm{Y})$ is significant with a $\mathrm{t}$-count of $3.694(\mathrm{t}$-count $>\mathrm{t}$ table $=1.98)$ and Sig. $=$ 0,000 . The coefficient value is negative that is equal to -0.699 which indicates that the direction of the relationship between Career development (X2) with Turnover Intention is negative at $69.9 \%$. Thus the $\mathrm{H} 2$ hypothesis in this study which states that "Career development (X2) has a significant effect on employee turnover intentions (Y)" is accepted.

3) There is a negative and significant influence from Job satisfaction (X3) to Turnover Intention (Y) partially.

Table 4 shows that the relationship between Job satisfaction (X3) and Turnover Intention $(\mathrm{Y})$ is significant with a t-test of $2.224(\mathrm{t}$-count $>\mathrm{t}$ table $=1.98)$ and the value of Sig. $=0.027$. The coefficient value is negative that is equal to -0.352 which indicates that the direction of the relationship between Job satisfaction (X3) with Turnover Intention is negative at $35.2 \%$. Thus the $\mathrm{H} 3$ hypothesis in this study which states that "Job satisfaction (X3) has a significant effect on Turnover Intention (Y) of Employees" is accepted.

4) Compensation, Career development and Job satisfaction simultaneously influence Turnover Intention.

Based on the results of the simultaneous significance test (f test) in table 4.15 above shows the F-calculated value of 66.244 (F-count> F-table $=2.69$ and Sig. $=0.000$, which indicates that the Compensation variable (X1), Career development (X2) and Job 
satisfaction (X3) variables together have a significant effect on Turnover Intention (Y) variables, thus the $\mathrm{H} 4$ hypothesis in this study which states that "Compensation, Career development and Job satisfaction simultaneously influence Turnover Intention " received.

\section{F-Test}

The $\mathrm{F}$ test is also called the simultaneous test or ANOVA. The F test is used to determine whether all independent variables in the regression series have a joint influence on the dependent variable. F-test results using SPSS 25 will be presented in the table below:

Tabel 5 F-Test Results

\begin{tabular}{|c|c|c|c|}
\hline \multicolumn{4}{|c|}{ ANOVA $^{a}$} \\
\hline Model & & $\mathrm{F}$ & Sig. \\
\hline \multirow[t]{3}{*}{1} & Regression & 66.244 & $.000^{\mathrm{b}}$ \\
\hline & Residual & & \\
\hline & Total & & \\
\hline \multicolumn{4}{|c|}{ a. Dependent Variable: TURNOVER INTENTION } \\
\hline \multicolumn{4}{|c|}{ b. Predictors: (Constant), COMPENSATION, } \\
\hline CARE & $\begin{array}{l}\text { ER DEVELOPN } \\
\text { (Source: data }\end{array}$ & $\begin{array}{l}\text { JOB SAT } \\
\text { ing, } 202\end{array}$ & ACTION \\
\hline
\end{tabular}

Based on table 5 above, known values of $F=66,244$, and Sig. $=0,000$, matching the value of $\mathrm{F}$ table with df $(3 ; 111)=2.69$. So, F count $>\mathrm{F}$ table. Thus H0 is rejected and Ha is accepted, this proves that the variable Compensation (X1), Career Development (X2) and Job satisfaction (X3) simultaneously have a significant effect on the Turnover Intention variable (Y).

\section{$\mathbf{R}^{2}$ Test}

$\mathrm{R}^{2}$ test is used to obtain information on the amount of contributions or contributions that the independent variable gives to the dependent variable. The results of the determination test can be seen in the following table:

\section{Table $6 \mathbf{R}^{2}$ Test Results}

\begin{tabular}{lc} 
Model & Adjusted R Square \\
\hline 1 & .636 \\
\hline a. Predictors: (Constant), Compensation, \\
Career development, Job satisfaction
\end{tabular}

b. Dependent Variable: Turnover Intention

(Source: data processing, 2020)

Based on table 6, note the value of Adjusted R Square $=0.636$. This shows that $63.6 \%$ Turnover Intention (Y) is influenced by the variable Compensation (X1), Career development 
(X2), and Job satisfaction (X3). The remaining contribution of $36.4 \%$ can be explained by other variables.

\section{Matrix Correlation}

Correlation test between dimensions is performed to determine the magnitude of the relationship between each dimension of all independent variables with each dimension on the dependent variable. Correlation test results using the Pearson's Correlation two-tailed method and will be described in the following table:

\section{Table 7 Correlation Matrix Between Dimensions}

\begin{tabular}{|c|c|c|c|c|c|c|}
\hline \multirow{2}{*}{ Variable } & \multirow[b]{2}{*}{ Dimension } & \multicolumn{5}{|c|}{ Turnover Intention (Y) } \\
\hline & & $\begin{array}{l}\text { 4.1 Desire } \\
\text { to out }\end{array}$ & $\begin{array}{l}\text { 4.2 Thinking } \\
\text { of getting out }\end{array}$ & $\begin{array}{l}4.3 \text { Effort } \\
\text { looking for } \\
\text { work }\end{array}$ & $\begin{array}{l}4.4 \mathrm{Job} \\
\text { attendance }\end{array}$ & $\begin{array}{l}\text { 4.5 Different } \\
\text { behavior }\end{array}$ \\
\hline \multirow{6}{*}{ Compensation (X1) } & 1.1 Salary & -0.643 & -0.675 & -0.617 & -0.717 & -0.669 \\
\hline & 1.2 Bonus & -0.576 & -0.586 & -0.566 & -0.647 & -0.566 \\
\hline & 1.3 Allowance & -0.586 & -0.492 & -0.537 & -0.527 & -0.498 \\
\hline & $\begin{array}{l}\text { 1.4 Opportunity to } \\
\text { develop abilities }\end{array}$ & -0.523 & -0.642 & -0.538 & -0.577 & -0.543 \\
\hline & 1.5 Work is appreciated & -0.518 & -0.525 & -0.559 & -0.542 & -0.604 \\
\hline & $\begin{array}{l}\text { 1.6 Flexibility of working } \\
\text { hours }\end{array}$ & -0.469 & -0.418 & -0.420 & -0.443 & -0.506 \\
\hline \multirow{6}{*}{$\begin{array}{c}\text { Career } \\
\text { development } \\
\text { (X2) }\end{array}$} & $\begin{array}{l}\text { 2.1 Career according to e } \\
\text { pertise }\end{array}$ & -0.691 & -0.577 & -0.607 & -0.647 & -0.640 \\
\hline & 2.2 Career wide open & -0.618 & -0.477 & -0.533 & -0.598 & -0.601 \\
\hline & 2.3 A career for the long term & -0.574 & -0.454 & -0.590 & -0.542 & -0.620 \\
\hline & 2.4 HR Planning & -0.506 & -0.496 & -0.555 & -0.546 & -0.536 \\
\hline & 2.5 Vacancy info & -0.455 & -0.497 & -0.470 & -0.524 & -0.445 \\
\hline & $\begin{array}{l}2.6 \text { Education and } \\
\text { training }\end{array}$ & -0.531 & -0.589 & -0.582 & -0.566 & -0.510 \\
\hline \multirow{6}{*}{$\begin{array}{l}\text { Job satisfaction } \\
\qquad(\mathrm{X} 3)\end{array}$} & 3.1 Monotonous work & -0.466 & -0.426 & -0.407 & -0.477 & -0.586 \\
\hline & $\begin{array}{l}3.2 \text { Work according to } \\
\text { interests }\end{array}$ & -0.526 & -0.530 & -0.434 & -0.536 & -0.530 \\
\hline & 3.3 Boss's direction & -0.457 & -0.509 & -0.493 & -0.510 & -0.521 \\
\hline & 3.4 Report to Boss & -0.445 & -0.506 & -0.482 & -0.472 & -0.544 \\
\hline & 3.5 Teamwork & -0.597 & -0.534 & -0.583 & -0.540 & -0.649 \\
\hline & $\begin{array}{l}.6 \text { Colleague } \\
\text { communication }\end{array}$ & -0.457 & -0.554 & -0.491 & -0.525 & -0.573 \\
\hline
\end{tabular}

(Source: data processing, 2020)

Based on table 7, can be explained that:

1) Variable Compensation (X1) to Variable Turnover Intention (Y)

Based on table 4.7 above it is known that the greatest correlation value between the dimensions in the Compensation (X1) variable to the Turnover Intention (Y) variable 
is the X1.1 dimension, namely the Salary dimension. Job attendance is -0.717 and belongs to the category of strong relationships. This e plains that dimension X1.3 Employees feel that the compensation dimension of the salary dimension is needed to support reducing Turnover Intention (Y). Higher pay that e plains salary.

2) Career development variable (X2) to Turnover Intention Variable (Y)

Based on table 4.7 above it is known that the greatest correlation value between the dimensions in the Career Development Variable (X2) to the Turnover Intention Variable (Y) is X2.1, that is, career does not match e pertise. The desire to stop with the Y4 dimension. This e plains that the X2.1 dimension that is career does not match e pertise in the variable Career development is needed to reduce Turnover Intention.

3) Job satisfaction variable (X3) to Turnover Intention Variable (Y)

Based on table 4.7 above it is known that the greatest correlation value between the dimensions in the Job Satisfaction Variable (X3) to the Turnover Intention Variable (Y) is the X3.5 dimension that is the dimension of teamwork. The desire to stop with the Y1 dimension. This e plains that the X3.5 dimension of teamwork dimensions in the Job satisfaction variable is needed to reduce turnover intention (Y).

The results of the study indicate that Compensation has a significant negative effect on Turnover Intention. The results of this study are supported by the results of previous studies conducted by Johannes et.al (2014) and Khadir \& Tinik Sugianti (2016).

The results of the study indicate that Career Development has a significant negative effect on Turnover Intention. The results of this study are supported by the results of previous studies carried out by Rijanti et.al (2016).

The results of the study indicate that Job Satisfaction has a significant negative effect on Turnover Intention. The results of this study are supported by the results of previous studies carried out by Johartono and Retnaningtyas Widuri (2013).

The results of research based on the $\mathrm{F}$ test show that Compensation, Career Development and Job Satisfaction simultaneously or simultaneously have a significant influence on Turnover Intention.

\section{CONCLUSION AND SUGGESTION}

Based on the results of data processing that has been shown in the previous chapter on "The Effect of Compensation, Career Development, Job Satisfaction on Turnover Intention of XYZ Company" then can draw conclusions as below:

1) The compensation variable has a negative and significant effect on Turnover Intention. This means that the higher the compensation given by the company, the lower Turnover Intention. Satisfaction compensation received by employees, especially the financial dimension consisting of salary, bonuses, benefits has a strong relationship to variable turnover intention, so that the desire of employees to find work with higher pay will be reduced if the company provides better compensation.

2) Career development variables have a negative and significant effect on Turnover Intention. This means that the better career development provided by the company, it 
will reduce turnover intention. Career development that has a strong relationship to variable turnover intention. So the desire of employees to find other jobs will be reduced if the career given by the company is better.

3) Job satisfaction variable has a negative and significant effect on Turnover Intention. This means that the better job satisfaction of an employee in a company, it will reduce turnover intention. Job satisfaction that has a strong relationship to variable turnover intention. So that the desire of employees to find other jobs will be reduced if the job satisfaction of an employee in a company is better.

4) Variable Compensation, Career development and Job satisfaction simultaneously have a significant effect on Turnover Intention. This means that the variable Compensation, Career development and Job satisfaction are getting worse, it increases Turnover Intention.

Based on the results of the study and the conclusions previously presented, the researcher provides input for school leaders and researchers who will further research as follows:

1) Researchers can then enter the variables or other factors that are suspected to affect Turnover Intention in addition to the variables or factors that exist in this study.

2) The foundation or the principal should increase simultaneously the Compensation, Career Development and Job Satisfaction of the employee to be more effective in reduce Turnover Intention.

3) The company is expected to be able to increase compensation staff such as bonus, extra leave day, as well as other funds.

4) The company is expected to be able to manage \& track career development staff so that they feel comfortable and happy to work.

5) The company is expected to be able to increase job satisfaction so staff feel comfortable and happy to work.

\section{REFERENCE}

Ansofino, Jolianis, Yolamalinda \& Arfilindo, H. 2016. Buku Ajar Ekonometrika. Deepublish:Yogyakarta. 
Biswakarma, Gangaram (2016). Organizational Career Growth and Employees ${ }^{\text {ee }}$ Turnover Intentions: An empirical evidence from Nepalese Private Commercial Banks. International Academic Journal of Organizational Behaviour and Human Resource Management Vol. 3, No. 2, 2016, pp. 10-26

Chaitra. M.P \& Murthy, T.P.R (2015). A Study on Employee Turnover. International Journal of Research in management. ISSN 2249-5908. Issue 5, Vol. 2

Chandio, J. A., Jhatial, A. A., \& Mallah, R. (2013). Modelling the relationship of unclear career development with job dissatisfaction, job stress and employees' turnover intention: Structural equation modelling approach. International Research Journal of Arts and Humanities, 41(41), 57-70.

Charles B. \& Irene C. (2018). The Influence Of Career Development, Organizational Culture, and Leadership On Turnover Intention At PT.CAFOM Sourcing. International Journal of Economics, Business and Management Research, Vol. 2. No. 06

Chieze, dkk. (2017). Working environment and Employees Job Satisfaction in Nigerian Banks. International Journal of Development Strategies in Humanities, Management and Social Sciences, Vol.7. Hard Print: 2360-903।

Dessler, Gary. (2015). "Human Resource Management. 14th ed. Pearson”. Penerbit Salemba Empat. Jakarta.

Dessler, Gary. (2016). "Human Resource Management. 15th ed. Pearson”. New Jersey.

Ferdinand, A. 2014. Metode Penelitian Manajemen: Pedoman Penelitian untuk Penulisan Skripsi Tesis dan Disertasi Ilmu Manajemen. Undip Press:Semarang.

Ghozali, I. 2013. Aplikasi Analisis Multivariate dengan Program IBM SPSS 21 Update PLS Regresi. Badan Penerbit Universitas Diponegoro:Semarang.

Han Guan Chew, dkk. (2016). Effect of Alternative Opportunities and Compensation on Turnover. International Journal of Humanities and Social Sciences, Vol.10, No:3, 2016

Herlina, V. 2019. Panduan Praktis Mengolah Data Kuesioner Menggunakan SPSS. PT Elex Media Komputindo:Jakarta.

Indra, I.M \& Cahyaningrum, I. 2019. Cara Mudah Memahami Metodologi Penelitian. Deepublish:Sleman.

Iqbal, S., Ehsan, S., Rizwan, M., \& Noreen, M. (2010). The Impact of Organizational Commitment, Job Satisfaction, Job Stress and Leadership Support on Turnover Intention in Educational Institutes. International Journal of Human Resource Studies, 4 (2), 181-95.

Ismail, F. 2018. STATISTIKA Untuk Penelitian Pendidikan dan Ilmu-ilmu Sosial. Prenadamedia Group:Jakarta.

Jian-Qiao Chen, Lovelace, Kathi. J, Zhi, Li, Wang. (2016). The Role of Career Growth in Chinese New Employee's Turnover Process. Journal of Career Development, Vol 43(1) $11-25,2016$

Johannes, Edward and Muchid Rofi'i. (2014). "Pengaruh Compensation and Iklim Organisasi to Turnover Intention dengan job satisfaction sebagai variabel intervening". Jurnal Dinamika Manajemen Vol.2 No. 2.

Johartono and Widuri, Retnaningtyas (2013). Analisa Pengaruh Stress Kerja, Job satisfaction, Budaya Organisasi and Komitmen Organisasi to Turnover Intention Karyawan Kantor Konsultan Pajak di Surabaya. Ta \& Accounting Review. Vol. 3, No .2

Kadarisman. (2012). Manajemen Pengembangan Source Daya Manusia. Raja Grafindo Persada. Jakarta.

Kanwal, Binish. (2016). Organizational Environment, Job Satisfaction and Career Growth Opportunities: A Link to Employee's Turnover Intentions in University of Sargodha, Pakistan. Journal of Resources Development and Management, Vol.20 
Karavardar, Gulsah, (2014). Organizational Career Growth and Turnover Intention: An Application in Audit Firms in Turkey. International Business Research; Vol. 7, No. 9; 2014, ISSN 1913-9004

Kasmir. (2016). "Manajemen Source Daya Manusia (Teori and Praktik)". Raja Grafindo Persada. Jakarta.

Li Yifei. (2018). Career Growth and Turnover Intention : The Mediator Role of Career Commitment and Organizational Identification. JEL Classification, J24;J63;J81

Luthans, Fred. (2011). Organizational Behavior: An Evidence-Based Approach. 12th Edition, McGraw-Hill/Irwin: New York.

Mahmud, K., and Idrish, S. (2011). The Impact of Human Resource Management Practices on Turnover of Bank Employees in Bangladesh. World review of Business Research. Vol. 1, No. 2, May 2011, pp: 71-83.

Mathis, Robert L. and Jackson John H. (2010). "Human Resource Management 13th ed.Thomson". South-Western.

Mondy, R. Wayne and Martocchio, Joseph J. (2016). "Human Resource Management. 14th ed. Pearson". London.

Nawaz, Muhammad Shahid, \& Pangil, Faizuniah. (2016). Career Concern as Predictor of Turnover Intention: Empirical Evidence from Education Industry. Asian Journal of Applied Sciences (ISSN: 2321 - 089), Volume 04 - Issue 02, April 2016

Ngantung, Gabriela R., David P. E. Saerang, and Merinda Pandowo. (2015). The Effect Of Job Stress, Workload And Work Environment On Employee Turnover. Jurnal Berkala Ilmiah Efisiensi. Vol. 15. No. 05, pp851-861

Noe, Raymond A., et all. (2014). "Human Resource Management Mc Graw-Hill”, New York

Nugraha, J. 2014. Pengantar Analisis Data Kategorik. Deepublish:Yogyakarta.

Nurnaningsih, S \& Wahyono. (2017). "Pengaruh Kepuasan Kerja, Motivasi Kerja dan Komitmen Organisasi Terhadap Kinerja Melalui Organizational Citizenship Behavior $(O C B)$ Sebagai Variabel Intervening ". Economic Education Analysis Journal. Vol. 6 (2), pp: 365-378.

Purnomo, R.A. 2017. Analisis Statistik Ekonomi dan Bisnis dengan SPSS. Wade Group:Ponorogo.

Quraeshi, M. I., et all. (2012). Job Stress, Workload, Enviroment and Employees Turnover Intentions: Destiny or Choice. Archieves Des Sciences, Vol. 65, No. B

Robbins,S,P and Judge,T,A. (2017). Organizational Behavior 17thEdition. Jakarta: Salemba Empat.

Sheraz, Ahmad; Wajid M, Sajid M, and Qureshi HW. (2014). Antecedens of Job Stress and its Impact on Employee's Job Satisfication and Turnover Intentions. International Journal of Learning \& Development. Vol. 4, No. 2.

Sugiyono. 2014. Metode Penelitian Kuantitatif, Kualitatif, dan Kombinasi (Mixed Methods). Alfabeta:Bandung.

Sunyoto. Andang. (2012). Teori, Kuesioner and Analisis Data Source Daya Manusia. Center for Academic Publishing Service. Yogyakarta.

Sutanto, Eddy M. and Gunawan Carin. (2013). Job satisfaction, Komitmen Organisasional and Turnover Intentions. Jurnal Mitra Ekonomi and Manajemen Bisnis. Vol. 4, No. 1,pp 7688

Sutrisno, Edy. (2009). Manajemen Source Daya Manusia. Kencana Prenada Media Group. Jakarta

Waspodo, Agung and Handayani, Nurul. (2013). Pengaruh Job satisfaction and Stress Kerja to Turnover Intention pada karyawan PT UNITE Bogor. Jurnal riset Manajemen Sains Indonesia (JRMSI). Vol. 4, No. 1 
Wati, L.A \& Primyastanto, M. 2018. Ekonomi Produksi Kelautan dan Perikanan: Teori dan Aplikasinya. UB Press:Malang.

Yamazakia, Yoshitaka and Petchdee, Sorasit. (2015). Turnover Intention, Organizational Commitment, and Specific Job Satisfaction among Production Employees in Thailand. Journal of Business and Management. Vol. 4 No.4,pp 22-38

Yang H., Ju Y., and Lee Y. (2016). Effects of Job Stress on Self-Esteem, Job Satisfication, and Turnover Intention. Journal of Transnational Management. Vol. 21, No. 1 